\title{
Ampliação da Revista
}

O crescente interesse pela revista - demonstrado pelo aumento substancial no número de trabalhos submetidos para publicação neste último ano indica agora que é necessária a ampliação do número de artigos a serem publicados na seção técnica. Esta preocupação foi objeto de debate na última reunião geral do Conselho Editorial da Revista, realizada em 29 de setembro passado, por ocasião do $4^{\circ} \mathrm{CBPol}$ em Salvador e, atualmente, tanto a Diretoria de Publicações da ABPol como o Comitê Editorial estão fazendo gestões no sentido de ampliar gradualmente, ainda neste ano de 1998, dos atuais seis para oito artigos publicados por edição. Entretanto, os problemas de logística envolvidos nesta ampliação requerem que os trabalhos submetidos doravante sejam mais compactos, evitando o avolumar das futuras edições. Neste sentido, chamamos a atenção para as alterações nas "Instruções para Apresentação de Trabalhos" da revista onde re-introduzimos as normas referentes à extensão máxima permitida nos trabalhos submetidos nas diversas categorias de artigos e comunicações.

Chamamos a atenção também para a preocupação que a revista mantém com a padronização da nomenclatura/terminologia utilizada na área de polímeros, especialmente nos artigos nela publicados. Esta é, sem dúvida, uma preocupação maior da toda a comunidade de polímeros no Brasil, e foi assunto de debate na última reunião do Conselho Editorial, que recomenda a padronização internacional adotada pela IUPAC, conforme já noticiado na seção de "Informes e Notícias" da última edição desta revista. Existe aqui um campo de atuação bastante fértil para a ABPol buscar a padronização da nomenclatura em polímeros, através das suas comissões técnicas.

Com o objetivo de disseminar as atividades de pesquisa ora desenvolvidas nas nossas universidades, listamos na seção de "Informes e Notícias" as dissertações/teses defendidas em 1997 nos diversos programas de pós-graduação com ênfase específico na área de polímeros, e desde já convidamos os docentes e, especificamente os coordenadores de programas de pós-graduação em polímeros que por ventura ainda não tenham sido contatados pela secretaria da revista, para fornecer os dados referentes aos seus programas.

Neste ano de comemoração dos 10 anos de existência da ABPol, a revista "Polímeros: Ciência e Tecnologia" reserva espaço especial para uma matéria curta relatando as atividades e realizações das três principais comissões técnicas da ABPol sobre "Identificação e Caracterização de Polímeros", "Reciclagem de Polímeros" e "Reologia e Processamento de Polímeros", que vêm ao longo dos anos desempenhando o papel importante de transmitir e intercambiar conhecimentos para geração de competência nos diversos setores de atuação da comunidade brasileira de polímeros.

Comitê Editorial 